\title{
Potensi Kitosan Bersumber dari Limbah Cangkang Rajungan (Portunus pelagicus) dalam Bidang Farmasi
}

Patihul Husni*, Junaedi Junaedi, Dolih Gozali

Departemen Farmasetika dan Teknologi Formulasi, Fakultas Farmasi, Universitas Padjadjaran, Jatinangor 45363

*email: patihul.husni@unpad.ac.id

(Submit 3/10/2019, Revisi 20/1/2020, Diterima 28/1/2020)

\begin{abstract}
Abstrak
Produksi rajungan (Portunus pelagicus) di Indonesia dalam satu tahun mencapai 30.000 ton yang yang menghasilkan sisa buangan limbah cangkang rajungan. Rajungan, memiliki kandungan kitin yang dapat diproses lebih lanjut melalui reaksi deasetilasi menjadi kitosan. Kitosan bersifat biocompatible dan biodegradable. Kitosan dalam bidang farmasi dimanfaatkan sebagai bahan eksipien obat dan belum banyak dimanfaatkan sebagai zat aktif obat. Dengan demikian, limbah cangkang rajungan memiliki potensi yang sangat besar untuk dijadikan produk yang lebih bermanfaat, yaitu berupa kitosan.
\end{abstract}

Kata kunci: rajungan (Portunus pelagicus), kitin, kitosan

\section{Outline}

- Pendahuluan

- Struktur Kitosan

- Proses Pembuatan Kitosan dari Cangkang Rajungan

- Sifat Fisika dan Kimia Kitosan

- Kesimpulan

- Daftar Pustaka

\section{Pendahuluan}

Asosiasi Pengelola Rajungan Indonesia (APRI) menyatakan bahwa jumlah produksi rajungan di Indonesia dalam satu tahun mencapai 30.000 ton. Sebagian besar dari produk rajungan Indonesia dimanfaatkan untuk kebutuhan ekspor berupa produk kemasan kaleng yang menghasilkan sisa buangan limbah cangkang rajungan (APRI, 2012).

Sejumlah penelitian menyatakan bahwa dalam hewan golongan kepiting, termasuk rajungan, memiliki kandungan kitin yang dapat diproses lebih lanjut melalui reaksi deasetilasi menjadi kitosan (Burrows, 2007, Yen, 2009). Kitin atau pun kitosan yang terkandung dalam sejumlah cangkang rajungan bisa mencapai $22,66 \%$ (Tanasale, 2012). 
Kitosan adalah molekul dengan struktur polisakarida mirip dengan selulosa, yang terdiri dari dua jenis unit berulang, $\mathrm{N}$-asetil-D-glukosamin dan D-glukosamin, dihubungkan oleh (1-4)- $\beta$-glikosidik linkage (Roberts, 1992). Kitosan adalah biopoliaminosakarida, polimer kationik yang diperoleh dari kitin melalui tahapan deasetilasi basa dan ditandai dengan kehadiran sejumlah besar kelompok amino pada rantai. Metode umum untuk sintesis kitosan adalah deasetilasi dari kitin yang biasanya berasal dari cangkang udang dan krustasea laut lainnya. Lalu, mereaksikan dengan larutan natrium hidroksida berlebih sebagai pereaksi. Kitosan tidak larut dalam air, larut dalam larutan asam asetat, sitrat, dan tartrat pada $\mathrm{pH}$ kurang dari 6,5. Namun, pada kondisi larutan asam fosfat dan sulfat, kitosan tidak larut. Selain itu, saat $\mathrm{pH}>6,5$ terbentuk endapan polisakarida dalam larutan air dengan bentuk seperti agar-agar (LeHoux, 1993, Struszczyk , 2002).

Kitosan memiliki sifat biocompatible dan biodegradable, bahkan di bumi terhitung sebagai senyawa biodegradable yang sangat melimpah dengan hasil biodegradasinya terdapat di air dan tanah. Karakteristik kitosan ditandai oleh derajat deasetilasi (DA), kemurnian setelah dilarutkan dalam asam organik, derajat polimerisasi, serta nilai BM (Schlaak, 2000). Besaran harga serta kualitas dari kitosan umumnya sejalan dengan besaran derajat deasetilisasi (Coma, 2002).

Aplikasi kitosan dalam bidang farmasi telah dilakukan oleh sejumlah penelitian seperti penghantaran obat (drug delivery), penghantaran protein/peptida/vaksin/gen/ oligonukleotida, wound dressing, protein binding, bioimaging, zat antimikroba pada makanan, antibakteri pada bahan kemasan makanan dan tekstil, implan, komponen lensa kontak dan enkapsulasi sel (Shariatinia, 2018).

\section{Struktur Kitosan}

Kitosan merupakan bentuk kopolimer kationik 2-glikosamin dan $\mathrm{N}$ - asetil-2-glukosamin. Kitosan memiliki rumus umum $\left(\mathrm{C}_{6} \mathrm{H}_{11} \mathrm{NO}_{4}\right)$ dengan berat molekul rata-rata 120.000 (Jagtap , 2009). Perbedaan dalam segi struktur antara kitosan dan kitin yaitu adanya gugus amino bebas yang reaktif. Kitin alami memiliki BM $1-2$ juta Da, terdiri atas 6000 - 12000 unit monosakarida. Hal berbeda terlihat pada BM kitosan yang relatif lebih rendah, dikarenakan adanya pemisahan rantai selama proses transformasi (Schlaak, 2000).

Pada gugus amina terdapat atom nitrogen sehingga menyediakan pasangan elektron bebas yang reaktif dengan kation logam. Pada kondisi $\mathrm{pH}$ asam, gugus amina mengalami protonasi sehingga terjadi peningkatan kelarutan kitosan yang bersifat tidak larut dalam pelarut alkali dan pada kondisi pH netral (Bernkop-Schnürch , 2004). Struktur kimia kitin dan kitosan dicirikan oleh derajat deasetilasi (DA) ditunjukkan pada Gambar 1. 


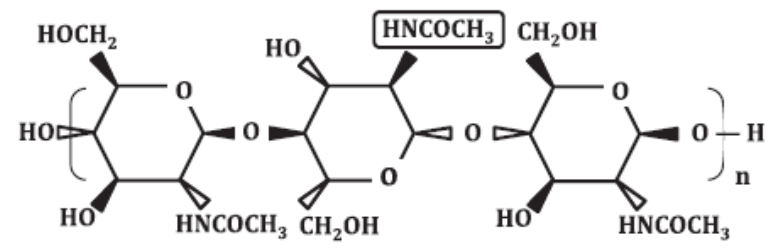

Chitin

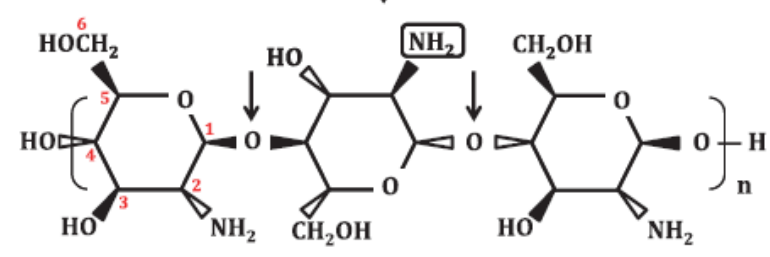

Chitosan

Gambar 1. Struktur Kimia Kitin dan Kitosan (Raafat, 2009).

Pada dasarnya sintesis kitosan sangat dipengaruhi oleh kondisi operasional pembuatan. Hal ini dikarenakan kondisi operasional seperti suhu mempengaruhi terhadap derajat deasetilasi yang berlanjut menentukan jumlah gugus amina bebas dalam rantai polimer kitosan. Selain gugus amina bebas, kitosan juga memiliki gugus hidroksil (Lee, 2009).

\section{Proses Pembuatan Kitosan dari Cangkang Rajungan}

Limbah cangkang rajungan mengandung senyawa kimia yang cukup banyak, antara lain protein sebesar $30-40 \%$; mineral $\left(\mathrm{CaCO}_{3}\right)$ sebesar $30-50 \%$; dan kitin $20-30 \%$ (Srijanto, 2003). Proses produksi untuk memperoleh kitin dari cangkang rajungan melalui beberapa tahap, yakni deproteinasi, delipidasi, dan demineralisasi. Kemudian, dilakukan proses deasetilasi guna memperoleh kitosan yang memenuhi syarat industri (Rahayu, 2004, Rahayu, 2007).

Adapun tahapan lebih rinci dari produksi kitin seperti dibawah ini (Rahayu, 2004):

1. Limbah cangkang rajungan dikeringkan, lalu digerinding dan ditapis menggunakan pengayak ukuran 100 mesh.

2. Cangkang rajungan dideproteinasi menggunakan larutan $\mathrm{NaOH} 2,0 \mathrm{~N}$ dengan perbandingan $1: 6(\mathrm{~b} / \mathrm{v})$ sambil diaduk dan dipanaskan pada suhu $80^{\circ} \mathrm{C}$ selama 1 jam.

3. Setelah dipisahkan dari larutannya, cangkang dicuci dengan air hingga netral.

4. Kemudian dikeringkan pada suhu $70-80^{\circ} \mathrm{C}$ selama 24 jam dalam oven.

5. Padatan kering hasil deproteinasi selanjutnya didemineralisasi dengan menggunakan larutan $\mathrm{HCl} 1,5 \mathrm{~N}$ (perbandingan $1: 12 \mathrm{~b} / \mathrm{v}$ ) dan diaduk pada suhu kamar selama 1 jam.

6. Setelah disaring, padatan dicuci dengan air hingga netral kemudian dikeringkan pada suhu $70-80^{\circ} \mathrm{C}$ selama 24 jam dalam oven untuk mendapatkan kitin kering. 
Produksi kitosan dilakukan dengan tahapan (Rahayu, 2007; Ahyat, 2017):

1. Proses deasetilasi dilakukan dengan merebus kitin dalam larutan $\mathrm{NaOH} 50 \%$ dengan perbandingan $1: 20(\mathrm{~b} / \mathrm{v})$ pada suhu $70 \mathrm{oC}, 80 \mathrm{oC}, 90 \mathrm{oC}$, dan $100 \mathrm{oC}$, masing-masing dengan waktu perebusan $30,60,90$, dan 120 menit.

2. Padatan kemudian dipisahkan dengan cairan, selanjutnya dicuci dengan aquadest hingga netral.

3. Setelah itu padatan dikeringkan pada suhu $70-80$ oC dalam oven selama 24 jam. Produk yang diperoleh dari proses ini dinamakan kitosan.

4. Pemastian produk yang dihasilkan adalah kitosan dilakukan dengan karakterisasi menggunakan Fourier Transform Infrared (FTIR) Spectroscopy, X-ray diffraction (XRD), CHNS elemental analysis dan Thermogravimetric analysis.

\section{Sifat Fisika dan Kimia Kitosan}

Karakteristik kitosan dapat dilihat dari tingkat kelarutan dalam asam lemah seperti asam asetat. Kitosan cenderung lebih meningkat kelarutannya jika dilarutkan dalam asam asetat $1-2 \%$ dan membentuk suatu garam ammonium asetat (Tang, 2007). Kitosan memiliki perbedaan yang sangat jelas dengan polisakarida lainnya, yakni memiliki muatan positif. Hal ini dapat terjadi disebabkan kitosan memiliki bentuk spesifik serta mengandung gugus amino dalam rantai karbon (Qin, 2006).

Gugus polisakarida yang dimiliki kitosan cukup banyak, tetapi tidak melebihi yang dimiliki selulosa. Berat molekul kitosan sebesar 1,036 × $105 \mathrm{Da}$. Berat molekul dari kitosan dipengaruhi oleh derajat deasetilasi yang dihasilkan saat setelah ekstraksi. Semakin banyak gugus asetil yang hilang dari polimer kitin, maka semakin kuat pula interaksi antara ion dan ikatan hidrogen serta peroksida dari kitosan (Tamura, 2002).

Secara umum, kualitas mutu dari kitosan ditentukan melalui beberapa parameter, diantaranya bobot molekul, kadar air, kadar abu, kelarutan, warna, dan derajat deasetilasi. Tabel 1 menunjukan standar mutu yang didasarkan pada spesifikasi untuk beberapa penerapan.

Tabel 1. Standar Mutu Kitosan

\begin{tabular}{|ll|}
\hline \multicolumn{1}{|c|}{ Spesifikasi } & \multicolumn{1}{c|}{ Kitosan komersial } \\
Penampakan warna & Putih, abu-abu, atau kuning \\
Granula & Bubuk atau serpihan \\
Derajat deasetilasi & $80 \% ; 85 \% ; 90 \% ; 95 \%$ \\
Viskositas dalam asam asetat 1\% (Cps) & $30-2000$ \\
Berat molekul & $10.000-2.500 .000$ \\
Kandungan kelembaban & $10 \%$ \\
Kandungan abu & $2,0 \%$ \\
Ketidaklarutan & $2,0 \%$ \\
pH (1\%) & $7-9$ \\
Logam berat & - \\
Total Plate Count & - \\
Coliform/ bakteri . coli & - \\
Kapang dan jamur & - \\
\hline
\end{tabular}




\section{Aplikasi Kitosan}

Aplikasi kitosan yang pernah dilaporkan yaitu kitosan sebagai carrier untuk elektroda (Kurniasih, 2012, Rismiarti, 2013), sebagai adsorben logam berat (Ali, 2013, Darjito, 2014, Sabarudin, 2013, Widwiastuti, 2013), sebagai penyerap lemak pada suplemen diet (Gades, 2005), serta sebagai antimikroba (Raafat, 2009). Umumnya, kitosan dalam bidang farmasi dimanfaatkan sebagai bahan eksipien obat dan belum banyak dimanfaatkan sebagai zat aktif obat. Kitosan sebagai zat eksipien obat dapat digunakan untuk pengemulsi (Liu, 2012), sistem sustained-release pada tablet, carrier, konjugat (Kato, 2003).

Tabel 2. Kitosan sebagai eksipien farmasi (Illum, 1998)

\begin{tabular}{|ll|}
\hline \multicolumn{1}{c|}{ Spesifikasi } & \multicolumn{1}{c|}{ Kitosan komersial } \\
Formulasi konvensional & Tablet cetak langsung \\
& Matriks tablet lepas lambat \\
& Granulasi basah \\
& Gel \\
& Film \\
& Emulsi \\
& Wetting agent \\
& Bahan penyalut \\
& Mikrosper dan mikrokapsul \\
\hline Aplikasi baru & Bioadhesi \\
& Transpor obat transmukosa \\
& Penghantaran vaksin \\
& Penghantaran DNA \\
\hline
\end{tabular}

\section{Kesimpulan}

Limbah cangkang rajungan sangat berpotensi sebagai bahan baku penghasil kitosan yang sangat berguna dalam bidang farmasi. Penggunaan limbah cangkang rajungan sebagai penghasil kitosan dapat meningkatkan nilai guna cangkang rajungan.

\section{Daftar Pustaka}

Ahyat, NM., Mohamad F., Ahmad A., and Azmi AA. 2017. Chitin and chitosan extraction from Portunus pelagicus. Malaysian Journal of Analytical Sciences, 21, 770-777.

Ali, M., Mulyasuryani, A., and Sabarudin, A. 2013. Adsorption of cadmium by silica chitosan. The Journal of Pure and Applied Chemistry Research, 2, 62-66.

APRI. 2012. Ekspor Rajungan Ketiga Terbesar Setelah Udang \& Tuna. Available: http://www.kemendag.go.id/en/news/2012/12/17/ekspor-rajungan-ketiga-terbesarsetelah-udang-tuna.

Bernkop-Schnürch, A., Hornof, M., and Guggi, D. 2004. Thiolated chitosans. European Journal of Pharmaceutics and Biopharmaceutics, 57, 9-17. 
Coma, V., Martial-gros, A., Garreau, S., Copinet, A., Salin, F., and Deschamps, A. 2002. Edible antimicrobial films based on chitosan matrix. Journal of food science, 67, 11621169.

Darjito, D., Purwonugroho, D., and Ningsih, R. 2014. The Adsorption of $\mathrm{Cr}$ (VI) Using Chitosan-Alumina Adsorbent. The Journal of Pure and Applied Chemistry Research, 3, 53-61.

Gades, M. D., and Stern, J. S. 2005. Chitosan supplementation and fat absorption in men and women. J Am Diet Assoc, 105, 72-7.

Illum, L. 1998. Chitosan and its use as apharmaceutical excipient. Pharmaceutical Research, 15, 1326-1331.

Jagtap, S., Thakre, D., Wanjari, S., Kamble, S., Labhsetwar, N., and Rayalu, S. 2009. New modified chitosan-based adsorbent for defluoridation of water. Journal of Colloid and Interface Science, 332, 280-290.

Kato, Y., Onishi, H., and Machida, Y. 2003. Application of chitin and chitosan derivatives in the pharmaceutical field. Curr Pharm Biotechnol, 4, 303-9.

Kurniasih, D., Atikah, A., and Sulistyarti, H. 2012. The coated-wire ion selective electrode (CWISE) of chromate using PVC-membrane based on chitosan as a carrier. The Journal of Pure and Applied Chemistry Research, 1, 33-40.

Lee, D. W., Lim, H., Chong, H. N., and Shim, W. S. 2009. Advances in chitosan material and its hybrid derivatives: a review. The Open Biomaterials Journal, 1.

Lehoux, J., and Grondin, F. 1993. Some effects of chitosan on liver function in the rat. Endocrinology, 132, 1078-1084.

Liu, H., Wang, C., Zou, S., Wei, Z., and Tong, Z. 2012. Simple, reversible emulsion system switched by $\mathrm{pH}$ on the basis of chitosan without any hydrophobic modification. Langmuir, 28, 11017-24.

Qin, C., Li, H., Xiao, Q., Liu, Y., Zhu, J., and Du, Y. 2006. Water-solubility of chitosan and its antimicrobial activity. Carbohydrate polymers, 63, 367-374.

Raafat, D., and Sahl, H. G. 2009. Chitosan and its antimicrobial potential--a critical literature survey. Microb Biotechnol, 2, 186-201.

Rahayu, L., dan Purnavita, S. 2004. Optimasi Proses Deproteinasi dan Demineralisasi pada Isolasi Kitin dari Limbah Cangkang Rajungan (Portunus pelagicus). Prosiding: Teori Aplikasi Teknologi Kelautan.

Rahayu, L., dan Purnavita, S. 2007. Optimasi pembuatan kitosan dari kitin limbah cangkang rajungan (Portunus pelagicus) untuk adsorben ion logam merkuri. Reaktor, $11,45-49$. 
Rismiarti, Z., Atikah, A., and Sulistyarti, H. 2013. Construction and Characterization of Coated Wire Oxalate Ion Selective Electrode Based on Chitosan. The Journal of Pure and Applied Chemistry Research, 3, 19-26.

Roberts, G. A. 1992. Structure of chitin and chitosan. Chitin Chemistry. Springer.

Sabarudin, A., and Motomizu, S. 2013. Functionalization of Chitosan with 3, 4, 5Trihydroxy Benzoic Acid Moiety for The Uptake of Chromium Species. The Journal of Pure and Applied Chemistry Research, 2, 48-54.

Shariatinia Z. Pharmaceutical applications of chitosan. 2019. Advances in Colloid and Interface Science, 263, 131-194.

Srijanto, B. Kajian pengembangan teknologi proses produksi kitin dan kitosan secara kimiawi. Prosiding seminar Nasional Teknik Kimia Indonesia, 2003.

Struszczyk, H., Pośpieszny, H. \& Gamzazade, A. 2002. Chitin and chitosan. PolishRussian monograph.

Tamura, H., Tsuruta, Y. \& Tokura, S. 2002. Preparation of chitosan-coated alginate filament. Materials Science and Engineering: C, 20, 143-147.

Tanasale, M. F., Killay, A., and Laratmase, M. S. 2012. Kitosan dari Limbah Kulit Kepiting Rajungan (Portunus sanginolentus L.) sebagai Adsorben Zat Warna Biru Metilena. Jurnal Natur Indonesia, 14.

Tang, Z.-X., Shi, L.-E., and Qian, J.-Q. 2007. Neutral lipase from aqueous solutions on chitosan nano-particles. Biochemical Engineering Journal, 34, 217-223.

Widwiastuti, H., Mulyasuryani, A. \& Sabarudin, A. 2013. Extraction of Pb2+ using Silica from Rice Husks Ash (RHA)-Chitosan as Solid Phase. The Journal of Pure and Applied Chemistry Research, 2, 42-47.

Yen, M.-T., Yang, J.-H. \& Mau, J.-L. 2009. Physicochemical characterization of chitin and chitosan from crab shells. Carbohydrate Polymers, 75, 15-21. 